\title{
Antinociceptive activity of Ricinus communis seed's hydroethanolic extract on male Balb/C mice
}

\section{Zahra Esfandyari ${ }^{1}$ Naser Mirazi $^{*}$ Abdolrahman Sarihi $^{3}$ Mahmoud Rafieian-Kopaei $^{4}$ (C)}

\author{
${ }^{1}$ Department of Biology, Faculty of Basic Sciences, Hamedan Branch Islamic Azad University, Hamedan, Iran. \\ ${ }^{2}$ Department of Biology, Faculty of Basic Sciences, Bu-Ali Sina University, Hamedan, Iran. E-mail: mirazi205@gmail.com. \\ ${ }^{*}$ Corresponding Author. \\ ${ }^{3}$ Department of physiology, Faculty of medicine, Hamedan University of Medical Sciences, Hamedan, Iran. \\ ${ }^{4}$ Medical Plants Research Center, Basic Health Sciences Institute, Shahrekord University of Medical Sciences, Shahrekord, Iran.
}

\begin{abstract}
Pain is a normal protective response to tissue injury caused by physical trauma, noxious chemicals and microbiological agents. Use of chemical drugs and medicinal plants is a conventional method to manage pain; however, their side effects have caused increased tendency to the use of herbal medicines among patients. This study was conducted to investigate antinociceptive action of Ricinus communis seed's extract (RCE) in male Balb/C mice. In this experimental study, 72 male mice weighing 25-35gr were used. Animals were randomly divided into six groups of 12 mice each, including: Control group, three groups separately treated respectively with 100, 200, and 400mg/kg hydroethanolic R. communis seed extract, morphine (1mg/kg)-treated group, and naloxone $(0.1 \mathrm{mg} / \mathrm{kg})+R$. communis seed extract (200mg/ $\mathrm{kg}$ )-treated group. All animals received extract and drugs intraperitoneally. To evaluate the analgesic effect of the extract, writhing and tail flick tests were used. The 200 and $400 \mathrm{mg} / \mathrm{kg}$ of the extract significantly increased pain threshold compared to the control group in writhing and tail flick tests $(P<0.01)$. Moreover, $400 \mathrm{mg} / \mathrm{kg}$ of the extract showed a stronger antinociceptive effect especially in writhing test compared to the control and other treated groups $(P<0.001)$. Analgesic effects of hydroethanolic $R$. communis seed extract observed in the tail flick and writhing tests are probably related to activation of opioid system. Results may suggest that this plant extract might be beneficial in relieving human pain.
\end{abstract}

Key words: antinociception, Ricinus communis, morphine, mice.

Atividade antinociceptiva do extrato hidroetanolico de sementes de Ricinus communis em ratos machos

RESUMO: A dor é um sentido com efeitos essencialmente protetores. Ouso de drogas químicas e plantas medicinais é um método convencional para gerenciar a dor, no entanto, seus efeitos colaterais têm causado uma maior tendência para o uso de ervas medicamentosas entre os pacientes. Este estudo nos levou a investigar as ações antinociceptivas do extrato de sementes de Ricinus communis (RCE) em camundongos machos. Neste estudo experimental, foram utilizados 72 camundongos machos com peso de $25 \pm 30$ gr. Os animais foram divididos aleatoriamente em seis grupos de 12 cada: grupo controle, três grupos tratados separadamente com 100,200 e $400 m g / k g$ de extrato de sementes de $R$. communis hidroetanolico, grupo tratado com morfina (1mg/kg) e naloxona $(0,1 \mathrm{mg} / \mathrm{kg})+R$. Grupo tratado com extrato de semente de communis $(200 \mathrm{mg} / \mathrm{kg})$. Para avaliar o efeito analgésico do extrato, utilizaram-se testes de contorção e cauda. Os dados foram analisados pela ANOVA e pelo teste de Tukey. P<0,05 foi considerado estatisticamente significante. Dose de 200 e $400 \mathrm{mg} / \mathrm{kg}$ de extrato aumentou significativamente o limite de dor em comparação com o grupo controle em testes de retorção e cauda (P<0,01). Além disso, 400mg/ $\mathrm{kg}$ de extracto apresentaram efeito antinoceptivo mais forte especialmente no teste de contorção em comparação com o controle e outros grupos tratados $(P<0,001)$. Os efeitos analgésicos do extrato de semente de $R$. communanolanol foram observados no teste da cauda e nos testes de contorção. Este efeito provavelmente está relacionado à ativação do sistema opioide.

Palavras-chave: analgesia, efeito antinociceptivo, Ricinus communis, ratos.

\section{INTRODUCTION}

Pain refers to protective, physical, and forced reflex. Painful stimuli generally induce strong withdrawal and avoidance responses. This sensation is highly complicated because when pain is elongated and tissue is damaged, central nociceptive pathways are sensitized and reorganized (GANONG, 2010) Pain sense message is received by nociceptors and reaches central nervous system through pain sensory nerve and transmitted into sensation guidance pathway in the spinal dorsal horn to second row nerves. 
These nerves are crossed and climb to spinal sidebar and reach thalamus in different sites of brain stem and specific relaying nuclei. Third row neurons lead sensory pain nerve to different parts of brain membrane and limbic system from these nuclei. Suffering from some types of pains in the long term imposes adverse mental effects on affected people so that humans have long been seeking out remedies to relieve or eliminate pain and many efforts have been made to explain pain mechanisms and treatment. To treat pain, two types of drugs, synthetic drugs and herbal drugs, are used (Solati et al. 2017; CHEVALIER,, 1996).

Opioids are still considered drugs of choice to treat severe pains; however, chronic use of opioids causes certain effects such as sleepiness, weakness, prostate disorders and delay in normal process of drainage, constipation, skin allergy such as hives, itching, dizziness, lack of concentration, heartbeat, and nausea (WAY et al., 2001). Opioid analgesics, which are used to relieve pain, are metabolized in the liver, cause numerous side effects including central nervous system disorders, respiratory system disorders, cardiovascular disease, smooth muscle contraction, gastrointestinal disorders, loss of consciousness, sleepiness, and addiction (KAPLAN \& SANDOCK, 1998).

Herbal drugs which are conventionally the essential oils or extracts of nature-based medicinal plants cause very few side effects; and therefore, are currently being increasingly investigated (HOSSEINZADEH SAMANI et al., 2017). Caster, scientifically called Ricinus communis L., is from family Euphorbiaceae and a herbaceous, annual, and single-based plant with influorescence green in upper parts and, in some types, single-based red flowers without petals. R. communis fruits are similar to spherical, acanaceous, and greenish capsules which become hard and brittle when they ripen.

$R$. communis seeds are wide, oval-shaped and similar to beans with glossy shells and a white, highly oily kernel inside them. $R$. communis seeds are brownish and greatly toxic (ZHANG et al , 2016).

Ricin, found in $R$. communis seeds, is a highly toxic protein (ZHANG et al, 2016). Antinociceptive activity of Ricinus communis leaves was evaluated and indicated that the extract exhibited considerable antinociceptive activity against pain in mice (TAUR et al. 2011). In light of the significance of pain management from medical perspective and since analgesic effects of the seeds of $R$. communis, which is an important medicinal plant, have not yet been investigated, we conducted this study to investigate the antinociceptive actions of Ricinus communis seed's extract (RCE) in male $\mathrm{Balb} / \mathrm{C}$ mice.

\section{MATERIALS AND METHODS}

\section{Plants gathering and extraction}

First, $500 \mathrm{~g}$ of $R$. communis seed was gathered from the Medicinal Plants Garden of Agriculture Jihad of Hamedan Province and then scientifically identified by the botanist of Bu-Ali Sina University, Hamedan. Samples were shadow dried under room temperature and then were pulverized with an electric mill.

$R$. communis seed powder was refrigerated in a beaker containing adequate amount of ethyl alcohol $80 \%$ for one week. Then, the contents inside the beaker were filtered by a filter paper and placed into a rotary instrument (at $55^{\circ} \mathrm{C}$ and $60 \mathrm{rpm}$ ) to separate the solvent and concentrate completely. The concentrated extract was placed in a petri dish under a hood to dry for 48 hours. The extract was frozen at $-20^{\circ} \mathrm{C}$ till use. Required doses of the extract were prepared with the concentrated extract and administered intraperitoneally (i.p). Each mouse was tested only once.

\section{Animals}

In this experimental study, 72 laboratory small white male mice weighing $25-35 \mathrm{~g}$ were purchased from Pasteur Institute of Iran. Mice were kept in Animals House for one week to reach stability and adapt to the environment. The animals keeping (temperature, humidity, light, feeding, and other biological factors) were controlled. Environment temperature was $22 \pm 2^{\circ} \mathrm{C}$ and its humidity $30-40 \%$. Regarding light conditions, mice were kept under 12-h dark/12-h light. The study protocol complies with the Principles of Ethical Conduct in the Use of Animals of Islamic Azad University of Hamadan.

\section{Animal grouping}

1. Control group (treated with $0.25 \mathrm{ml}$ normal saline); 2. Morphine-treated group $[1 \mathrm{mg} / \mathrm{kg}$ body weight $(\mathrm{BW})]$; 3. Low dose-treated group $(100 \mathrm{mg} / \mathrm{kg}$ BW of hydroethanolic $R$. communis extract);

4. Moderate dose-treated group (200mg/kg BW of hydroethanolic $R$. communis extract);

5. High dose-treated group $(400 \mathrm{mg} / \mathrm{kg} \mathrm{BW}$ of hydroethanolic $R$. communis extract); and

6. Naloxone+extract-treated group $(0.1 \mathrm{mg} / \mathrm{kg}$ naloxone and $200 \mathrm{mg} / \mathrm{kg}$ hydroethanolic $R$. communis extract). Naloxone was used as an opioid antagonist to examine the possible effect of the extract through opioid system.

Method of measuring pain according to tail flick test In all the groups, before administrations of the treatments, tail flick test was run in triplicate with 
Tail-flick 5500 (Borj Sanat, Iran). After administration of the treatments, tail flick test was run again in triplicate with 20 -min intervals. The mean value of the three tests' results was used in data analysis. This test is used to investigate central analgesic effects of drugs and chemical compounds, and is sensitive to drugs that act on the central nervous system.

In this test, pain is measured by the duration of delay in tail's reaction to thermal damage to tissue through shining of a light beam on the end of tail on ventral or dorsal surface. This delay is considered an index to measure pain (HEJAZIAN et al., 2008).

According to this method, the intensity of the used light was 7 and the reference duration of $10 \mathrm{~s}$ was considered to be cut off time, i.e, if the mouse did not flick its tail after 10s of shining the burning light, the stimulus was discontinued to prevent tissue damage. The mice were kept in horizontal position in a special box as they could move their tails freely. The duration of delay in flicking tails was measured in triplicate $2 \mathrm{~min}$ after the administration. Animals that exhibited delay of over $6 \mathrm{~s}$ in at least two of the three tests were excluded from the study.

Then, 20min after administrations, the test was run again in triplicate and the mean values were considered to be the delay duration after treatments administration.

In addition to the delayed response, represented by delayed flicking of the tail, the data of this test were used to estimate the percentage of maximal possible effect (MPE) according to the formula below: (Time of delayed response after administrationtime of initial response/cutoff time-time of initial response) $\times 100$. $\frac{\text { Time of delayed responce after adminstration - Time of initial responce }}{\text { Cut off time }- \text { Time of initial responce }} \times 100$

Method of measuring pain according to writhing test Mice were assigned to different groups to undergo writhing test in the same manner as they were assigned to different groups to undergo tail flick test. Writhing test is a chemical stimulation which is generally used to investigate chemical compounds with peripheral analgesic action. This test is much more efficient to investigate central or peripheral pain. Intraperitoneal administration with acetic acid can cause peritoneal inflammation that induces a response associated with abdominal muscle alongside body stretching. This writhing response is considered to be one of the most important models for visceral inflammatory pain (DASHTI et al., 2006).

On the day of the test, each mouse was kept in a standard glass box for 30min before the test to adapt to the environment. First, normal saline was i.p administered. Fifteen min later, $0.1 \mathrm{ml}$ acetic acid $0.6 \%$ was administered and $5 \mathrm{~min}$ later, abdominal contractions were counted for $30 \mathrm{~min}$.

In each turn, writhing was conducted by stretching abdominal and side muscles simultaneously with stretching out hind legs and measured according to the reflex of hind legs' paws within a few seconds. Each mouse was used only once. The mouse of the extract-treated groups were administered with 100, 200, and $400 \mathrm{mg} / \mathrm{kg}$ BW hydroethanolic $R$. communis seed extract dissolved in sterile physiology serum which was i.p administered and the test run. Then, the group administered with naloxone $+200 \mathrm{mg} / \mathrm{kg}$ BW of the studied extract and morphine-treated group were tested. Drugs used in this study were morphine sulfate $10 \mathrm{mg} /$ $\mathrm{kg}$ (DarouPaksh Co, Iran) and naloxone hydrochloride $0.4 \mathrm{mg} / \mathrm{ml}$ (Tolidaru, Iran).

\section{Data analysis}

SPSS 20 was used to analyze the data. Normal distribution of the data was investigated by Kolmogorov-Smirnov test and confirmed. Oneway ANOVA was used for making inter-group comparisons and Tukey's test for investigating difference between the two groups. The data were expressed as mean \pm SEM and $P<0.05$ was considered the level of statistical significance.

\section{RESULTS}

Comparative study of tail flick test results in different groups before and after the experiments

As figure 1 illustrates, the groups administered with low and moderate dose $(\mathrm{P}<0.05)$ were significantly different from the control group $(P<0.01)$. Furthermore, the group administered with naloxone $(0.1 \mathrm{mg} / \mathrm{kg})+$ extract $(200 \mathrm{mg} / \mathrm{kg})$ and the control group were not significantly different. Morphine-treated group exhibited a significantly increased time to flick the tail compared to the control group $(\mathrm{P}<0.001)$.

\section{Estimating percentage of the MPE in the studied groups} According to figure 2, the estimated mean MPE in all the groups administered with hydroethanolic $R$. communis seed extract (HRE) increased significantly compared to the control group $(P<0.001)$ in a markedly dose-dependent manner. The mean MPE in the group administered with $0.1 \mathrm{mg} /$ $\mathrm{kg}$ naloxone $(0.1 \mathrm{mg} / \mathrm{kg})+200 \mathrm{mg} / \mathrm{kg}$ HRE increased compared to the control group $(P<0.01)$, and decreased compared to the groups administered with different concentrations of the extract $(P<0.01)$ with more 


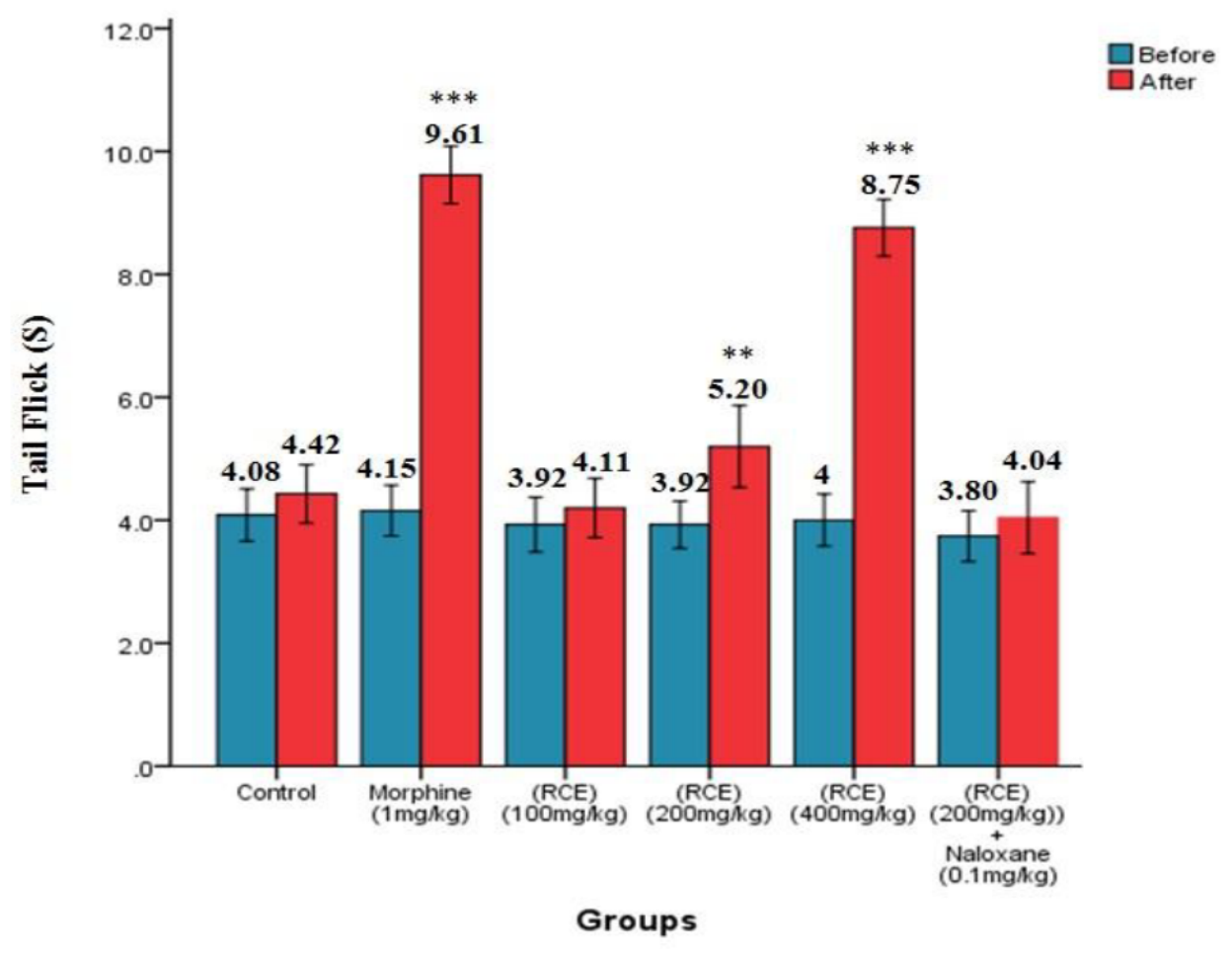

Figure 1 - Comparative study of tail flick test results in control group, the groups administered with hydroethanolic Ricinus communis seed extract (HRE), $(100,200$, and $400 \mathrm{mg} / \mathrm{kg})$, and the groups administered with naloxone $(0.1 \mathrm{mg} / \mathrm{kg})+\mathrm{HRE}(200 \mathrm{mg} / \mathrm{kg})$ in male mice. "Significant compared to before the test $\left({ }^{* *} P<0.01\right),\left({ }^{* * *} P<0.001\right)$. Figure after reference. See instructions to authors. There is no need to repeat number over bars if you already have a scale like $0,2.0$ etc etc.

marked difference compared to the group administered with $400 \mathrm{mg} / \mathrm{kg}$ BW of the extract $(P<0.001)$.

The three groups administered with $1 \mathrm{mg} /$ $\mathrm{kg}$ morphine alongside other studied groups exhibited significant increase compared to the control group and the group administered with $2 \mathrm{mg} / \mathrm{kg}+200 \mathrm{mg} / \mathrm{kg} \mathrm{HRE}$ $(P<0.001)$.

Study of writhing test results in the studied groups As figure 3 illustrates, the groups administered with 200 and $400 \mathrm{mg} / \mathrm{kg}$ exhibited a significant difference compared to the control group $(P<0.001)$. The group administered with $400 \mathrm{mg} / \mathrm{kg}$ exhibited a significantly increased abdominal contractions compared to morphinetreated $(1 \mathrm{mg} / \mathrm{kg})$ group $(P<0.001)$. Moreover, the group administered with $200 \mathrm{mg} / \mathrm{kg}+0.1 \mathrm{mg} / \mathrm{kg}$ naloxone was significantly different in writhing and tail flick tests compared to the group administered with $200 \mathrm{mg} / \mathrm{kg}$.

\section{DISCUSSION}

Nature-based opioids such as morphine are considered to be the most important analgesic drugs which are derived from poppy. Generally, opiates act on three opioid receptors $(\delta, \kappa$, and $\mu)$ in the central nervous system to relieve pain (MOMIN \& NAIR, 2004). These drugs are particularly significant to treat chronic pain. Although, morphine has been considered to be a pioneering pain-relieving agent for centuries, they are not completely safe. Morphine is addictive and can cause certain side effects such as respiratory disorders, napping, decreased gastrointestinal movements, nausea, and variations in autonomic and endocrine nervous system (PIR-NAZAR, 1998).

Available evidence indicates that the compounds present in food supplements and medicinal plants including food fibers, vitamins, flavonoids, 


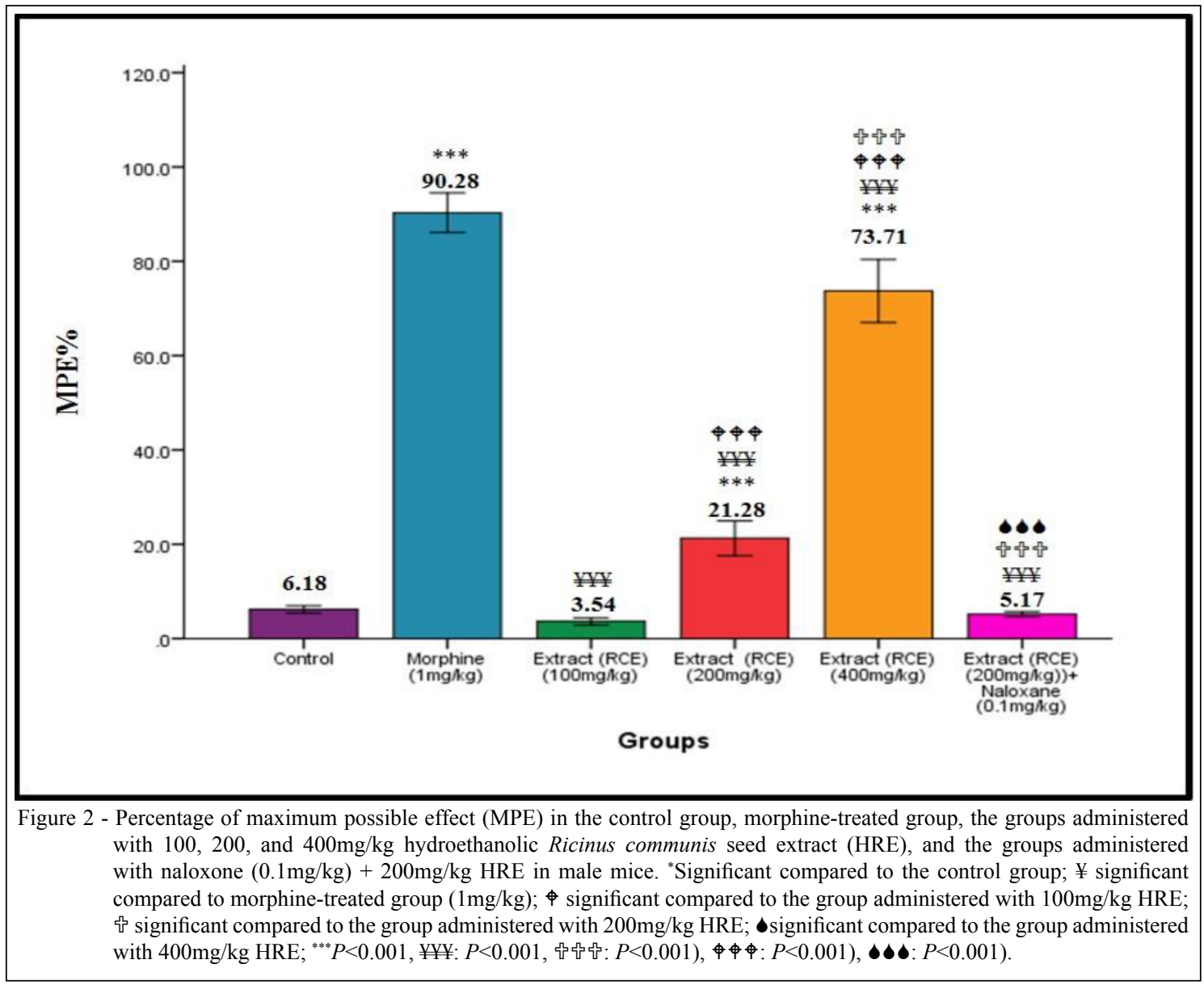

sterols, and other antioxidant compounds can contribute to analgesia through acting on central or peripheral nervous tissue (ZARGARI, 1997). Hydroethanolic $R$. communis seed extract is rich in flavonoid compounds such as quercetin, catechin, kaempferol, sinapic acid, and apigenin (SUBUDHI \& BHOI, 2011). Catechin in $R$. communis causes suppression of inflammation through acting on and being involved in inflammatory mechanisms, exerting anti-inflammatory effects, and inhibiting the enzymes involved in this pathway such as lipoxygenase and cyclooxygenase (YESI et al. 2004).

In the present study, the capability of hydroethanolic $R$. communis seeds' extract to relieve pain was investigated. Administration with 200 and $400 \mathrm{mg} / \mathrm{kg}$ hydroethanolic $R$. communis seed extract, in writhing test, caused significant decrease in abdominal contractions compared to the control group. Therefore, $R$. communis extract can be suggested as an agent with peripheral analgesic effects. Intraperitoneal administration with acetic acid can cause acute inflammation in peritoneum which induces an abdominal contraction-associated response alongside body stretching. This response to writhing is considered to be one of the most important visceral pain models (CHEN et al. 2007).

Regarding the findings, we can argue that hydroethanolic $R$. communis seed extract exerts its actions at least partly through opioid receptors and partly through cyclooxygenase system. It seems that $R$. communis extract can exert analgesic actions through affecting central and peripheral nervous system.

In tail flick test, intraperitoneal administration with $0.1 \mathrm{mg} / \mathrm{kg}$ naloxone was found to have no effects on analgesic action of $200 \mathrm{mg} / \mathrm{kg}$ hydroethanolic $R$. communis seed extract. However, in writhing test, naloxone administration caused decrease in analgesic action of this extract. The present study demonstrated that administration with 200 and $400 \mathrm{mg} / \mathrm{kg}$ hydroethanolic $R$. communis seed extract caused relief of thermal stimulus-induced pain in tail flick test. Besides that, $100 \mathrm{mg} / \mathrm{kg}$ hydroethanolic $R$. communis seed extract caused no significant relief of thermal stimulus-induced pain in tail flick test. This lack of effect in tail flick test 




can be due to synergistic effect of the compounds that react with other adrenoreceptors such as $\alpha_{2}$ in the spine.

To explain these findings, we can argue that abdominal contractions are associated with the sensitivity of pain receptors to some compounds such as prostaglandins. Tissue damage causes release of certain compounds such as prostaglandins, bradykinine, serotonin, $\mathrm{P}$ substance, and histamine (PINARDI et al. 2003). These mediators are released from damaged sites and stimulate pain receptors. Therefore, $R$. communis is likely to induce analgesic actions through synthesis of the inhibitors of these compounds such as prostaglandins. The observations in this study may also suggest that prostaglandins are involved in the analgesic actions of $R$. communis.

The analgesic actions of opioid antagonist and non steroidal anti-inflammatory representatives can be detected by abdominal contractions. This method can be naturally used to investigate the peripheral analgesic actions of the drugs (PAYAN \& KATZUNG 2015). Naloxone is one of the antagonist drugs of opioid system which prevents activation of opioid receptors. Naloxone inhibits effects of analgesic drugs such as morphine and even prevents induction of analgesia. Naloxone tends highly to absorb $\mu$ opioid receptors in central nervous system. Moreover, naloxone is a competitive antagonist for $\mu$ receptors. Besides that, naloxone is considered to be a competitive antagonist for $\delta$, k receptors yet less markedly compared to $\mu$ receptors (HOSSEINZADEH et al. 2000).

Apigenin causes decrease in the response due to stimulation of NMDA receptors in cortical neurons in culture medium. Apigenin is a protective agent against glutamate-induced toxicity in cortical neurons. Therefore, apigenin can exert antagonist effects on NMDA channels. Apigenin analgesic actions can be explained in the light of its effects on neural network. Apigenin directly target NF- $\kappa B$ and prevent it from binding to DNA, which regulates iNOS expression (LOSI et al. 2004).

Inhibitory effects of flavonoids on acute and chronic inflammation are due to their effects on signaling pathways including NF- $\mathrm{KB}$ activity and MAP 
kinase phosphorylation. Besides that, apigenin reduces accumulation of floating lipids that are required to signal pain. Therefore, flavonoids reduce acute and chronic inflammation by inhibiting accumulation of the receptors and signaling cascade (ROGHANI, 2015).

Results of this study indicated that the analgesic effects of this extract in acute phase were exerted at least partly through glutamanergic pathways. Over the years, the role of nitric oxide as a signaling molecule that can stimulate diverse biological responses has been known. This molecule can be produced in spinal neurons and plays an important part in processing pain messages (NEVEEN et al., 2007). Flavonoids have been demonstrated to cause decrease in activity of intracellular calcium by inhibiting NMDA receptors' activity, and consequently the activity of nitric oxide synthase and calcium-dependent phospholipase 2 decreases. Therefore, flavonoids exert analgesic effects by decreasing nitric oxide and prostaglandins. Quercetin's flavonoid prevents expression of iNOS and production of nitric oxide by suppressing NF- $\mathrm{B}$ activity and preventing phosphorylation and nuclear translocation in macrophages (KIASALARI et al. 2007). Hydroethanolic $R$. communis seed extract can inhibit production of nitric oxide because of containing certain flavonoids such as quercetin, kaempferol, and apigenin, which can partly explain the analgesic effects of this extract.

Although, in this study the analgesic activity of R. communis and the possible role of opioid system were revealed for the first time, but we did not analyzed the extract and could not show the main ingredient of the extract causing analgesia. Other negative aspect of the article is that $R$. communis seed extract was not standardized. Contents of the plant products vary according to various factors including the environmental and geographical positions. Therefore, it was better to standardize and analyze the extract.

\section{CONCLUSION}

Analgesic effect of $R$. communis seed extract was dose-dependent, at least within the spectrum of the studied concentrations, and increased with increase in dose. Reduced cramping and increased analgesic time of flicking tail confirm the plant's analgesic actions. It seems that the analgesic effect of $R$. communis is due to flavonoids or other composition such as apigenin contained in it. In addition, opioid pathway is likely one of the pathways through which the extract exerts its analgesic actions. It should be noted that we evaluated the antinociceptive activity of the extract in acute examination. We should evaluate the chronic effects, including the adverse effects of this extract in human to realize its advantage or disadvantage over available opioid drugs.

\section{ACKNOWLEDGMENTS}

This article was derived from an MSc dissertation of Zahra Esfandyari which was done in Animal Physiology at Basic Sciences Faculty of Islamic Azad University of Hamadan, Iran, that was greatly supported by the Research Deputy of this university.

\section{REFERENCES}

BASBAUM, A.I.; FIELDS, H.L. Endogenous pain control systems, brainstem spinal pathways and endorphin circuitry. Annu Rev Neurosci. Vol 7, p.309-3038. 1984. Available from: <https://doi. org/10.1146/annurev.ne.07.030184.001521>. Accessed: Oct. 31. 2006.

CHEN, H.S. et al. Roles of zapsaic insensitive primary afferents in differential rat models of inflammatory pain: a systematic comparative study in conscious rats. Experimental Neurology, vol 204 n1, p.244-251. 2007. Available from: $<$ https://www.sciencedirect.com/ science/article/pii/S0014488606006066?via\%3Dihub>. Accessed: Oct. 31, 2006. doi: 10.1016/j.expneurol.2006.10.011.

CHEVALIER, M.H. The Encyclopedia of Medicinal Plant. London. Dorling Kindersley. P.171-182. 1996.

DASHTI,M.H. etal. The analgesic effect of Carum copticum extractand morphine on phasic pain in mice. Journal of Ethno-pharmacology, vol 109, p. 226-228. 2007. Available from: <https://pdfs.semanticscholar. org/2865/d5e028ade9048a5d2f95ba51d0a22826224d.pdf $>$. Accessed: Jul. 20, 2006. doi:10.1016/j.jep.2006.07.035.

GANONG, W. Review of Medical Physiology: Translated by Ghasemi K. Tehran, Iran. Sina-teb Institute; 2010. [Persian]

HEJAZIAN, S.H. et al. Antinociceptive effects of carum copticumextract in mice using formalin test. World Applied Science Journal. Vol 3, 2 , p.215-219. 2008. Available from: <https://www.ncbi.nlm.nih.gov/pmc/ articles/PMC3501921/>. Accessed: Jul. 20, 2012.

HOSSEINZADEH SAMANI, B. et al. Effect of ultrasound and infrared drying methods on quantitative and qualitative characteristics of Satureja bachtiarica essential oil. Journal of Essential Oil Bearing Plants, vol 20, n 5, p.1196-1208. 2017. Available from: $<$ https://doi.or g/10.1080/0972060X.2017.1375868>. Accessed: Apr. 10, 2000.

HOSSEINZADEH, $\mathrm{H}$. et al. Antinociceptive, anti-inflammatory and acute toxicity effects of Zataria multiflora Boiss extracts in mice and rats. Journal of Ethnopharmacology. Vol 73, n 3, p, 379-85, 2000. Available from: <https://www.sciencedirect.com/science/article/ pii/S0378874100002385>. Accessed: Apr. 10, 2000. doi: S03788741(00)00238-5.

KAPLAN, H.; SANDOCK, B. Synopsis of Psychiatry, $8^{\text {th }}$ ed, Baltimore, Williams and Wilkins 1998.

KIASALARI, Z. et al. Evaluation of the effect of hydro-alcoholic extract of henbane seed on acute and chronic pain in male rats. Koomesh, Journal of Semnan University of Medical Sciences, vol 4, n 8, p.239-245 2007. [Persian]. Available from: <https:// goums.ac.ir/journal/article-1-617-en.pdf>. Accessed: Nov. 25, 2009. 
LOSI G. et al. Apigenin modulates GABAergic and glutamatergic transmission in cultured cortical neurons. European Journal of Pharmacology, vol 502 n 1 p.41-46. 2004. Available from: $<$ https:// www.sciencedirect.com/science/article/pii/S0014299904009562>. Accessed: Aug. 19, 2004. doi: 10.1016/j.ejphar.2004.08.043.

MOMIN, R.; NAIR, M. Antioxidant, cyclooxygenase and topoisomerase inhibitory compounds from Apium graveolens Linn Seeds. Phytomedicine. Vol 9, n 4, 312-318, 2002. Available from: $<$ https://doi.org/10.1078/0944-7113-00131>. Accessed: Nov. 10, 2004.

NEVEEN H. et al. Antidiabetic effects of Fenugreek alkaliod extract in Streptozotocin induced hyperglycemic rats. Journal of Applied Sciences Research, vol 3 n 10, p.1073-1083. 2007. Available from: <https://www. researchgate.net/profile/Abdel Razik Farrag/publication/228355441 Antidiabetic_Effects_of_Fenugreek_Alkaliod_Extract_in_Streptozotocin Induced Hyperglycemic Rats/links/0fcfd5138b-483b162000000/ Antidiabetic-Effects-of-Fenugreek-Alkaliod-Extract-in-StreptozotocinInduced-Hyperglycemic-Rats.pdf>. Accessed: Nov; 4, 2002.

PAYAN, D.; KATZUNG, B. Nonsteroidal anti-inflammatory drugs; nonopioid analgesics; drugs used in gout. Basic and Clinical Pharmacology, vol 21, n 3, p.536-59. 1995. Available from: <http:// armaghanj.yums.ac.ir/article-1-1007-fa.pdf>. Accessed: Dec. 17, 2015.

PINARDI, G., et al. Atropine reverses the anti-nociception of nonsteroidal anti-inflammatory drugs in the tail-flick test of mice. Journal of Pharmacology Biochemistry Behavior, vol 74, n 3, p .603-608. 2003. Available from: $<$ https://doi.org/10.1016/S0091-3057(02)010468>. Accessed: Nov. 4, 2002. doi: S0091-3057(02)01046-8.

PIR-NAZAR, A. Investigation of aqueous extract of saffron on tolerance of antinociceptive effect of morphine in male mice. [MSc thesis]. Baqiyatallah University of Medical Sciences. 1998: 10-24. [Persian].

ROGHANI M. Evaluation analgesic hydroalcoholic extract of fenugreek in male diabetic rats. Medicinal Plants, vol 32, n 1, p.8-12, 2000. [persian] Available from: $<$ http://armaghanj.yums.ac.ir/article1-1007-en.pdf $>$. Accessed: Dec. 17, 2015.
SOLATI, K. et al. Effects and mechanisms of medicinal plants on dopamine reward system to reduce complications of substance abuse: A Systematic Review. Middle East Journal of Family Medicine, vol 7, n 10, p.202. 2017.

SUBUDHI, B.B.; BHOI. A. Antioxidative effects of Brassica juncea and Moringa oli efera prepared by different processing methods. J Food Sci Technol, vol 51, n 4. p. 7904. 2014. Available from: <https://link.springer.com/content/ pdf/10.1007\%2Fs13197-011-0542-6.pdf >. Accessed: Sept. 26, 2011. doi: 10.1007/s13197-011-0542-6.

TAUR, D.J. et al. Antinociceptive activity of Ricinus communis leaves. Asian Pac J Trop Biomed. Vol 1, n 2, p.139-41. 2011. Available from: <https:/www.sciencedirect.com/science/article/ pii/S2221169111600129?via\%3Dihub>. Accessed: Apr. 1, 2011.

WAY, W.L. et al. Opioid analgesics and antagonists. In: Katzung BG, ed. Basic and Clinical Pharmacology. USA: Lange Medical Books/McGraw-Hill Companies: p.512-32. 2001.

YESILADA E., et al. Isolation of anti-ulcerogenic sesquiterpene lactones from Centaurea solstitialis L. ssp. solstitialis through bioassay-guided fractionation procedures in rats. J Ethnopharmacol, Vol 9, 2-3, p.213-219. 2004. Available from: <https://ac.els-cdn. com/S0378874104003927/1-s2.0-S0378874104003927-main.pdf? tid $=18 \mathrm{~b} 7 \mathrm{f} 7 \mathrm{c} 9$-bded-4aee-8795 0beaf725a0d3\&acdnat $=1523083948$ _8d095bc1098247af59f417a44563b6d6>. Accessed: Jul. 12, 2004. doi: 10.1016/j.jep.2004.07.021.

ZARGARI, A. Iranian Medicinal Plants. 6 ed. Tehran: Tehran University, vol 3 p. 243. 1997. [persian]

ZHANG, Y. et al. High light exposure on seed coat increases lipid accumulation in seeds of castor bean (Ricinus communis L.), a nongreen oilseed crop. Photosynth Res. vol 128 n 2, p. 12540. 2016. Available from: <https://link.springer.com/content/ pdf/10.1007\%2Fs11120-015-0206-x.pdf>. Accessed: Nov. 14, 2015. doi: 10.1007/s11120-015-0206-X. 